\title{
A HISTÓRIA E A NOVELA $\left({ }^{\star}\right)$.
}

O tema das relações da História com a Literatura tem merecido a preferência e a atenção dos tratadistas.

O problema poderia apresentar-se dentro da eterna quimera de realizar uma síntese perfeita de Verdade e Beleza. Dêste ângulo se trataria o ponto em que são tangentes a Estética, a Filosofia e a Ciência em suas relações inevitáveis. Essa colocação traria a vantagem de iludir os pronunciamentos de especialistas, sempre zelosos de "seu conhecimento", e portanto incapazes de compreender o pensamento humano em sua totalidade cultural.

Preferimos tratar o problema através de suas soluções históricas, vigentes na ocasião, mas que mesmo caducas persistem em um estado que se pode dizer "arqueológico", mas mesmo assim podendo ser encontradas no pensamento de muitos contemporâneos.

Outra possibilidade é abordar a relação que vincula concretamente a História a cada um dos gêneros literários. Nada pode ser mais interessante neste caso que

\section{"A fauna poética mais caracteristica dos últimos cem anos",}

como dizia, referindo-se à Novela, Ortega y Gasset.

As posições que através da História do pensamento têm despertado a consideraçã̉o dos homens e estão de acôrdo com c nosso critério são as seguintes:

No princípio a História e a Novela demonstram gôsto pela ficção, pela curiosidade simples, sem ulterioridades científicas, estéticas ou de ação que possam perturbar essa necessidade pueril.

A História primeiro e depois a Novela ingressam no seio da Literatura e com fortuna diferente sião consideradas gêneros literários, um tanto na penumbra ante o êxito da poesia e do teatro. Já na época contemporânea o afã científico tira

(*). - Texto espanhol traduzido por Maria Lúcla Galvão Carneíro (Nota da Redaçáo). 
a História da Literatura e a converte numa Ciência, e a entende então completamente desvinculada do helo e naturalmente da Novela. Esse mesmo excesso engendra uma reação que vincula, talvez pela primeira vez numa forma crgânica, a História à Filosofia e à Literatura. Essa última relação se robustece a tal ponto que o nosso século presencia a tendêencia de confundir em uma unidade já inclassificável a História e a Novela. Devido a isto a opinião predominante mostra como êsse movimento se superpõe e em definitivo traduz de um modo espúrio um eco mais importante. Trata-se do crescimento da idéia de historicidade que por intermédio das vinculações e interações de utilidade prática entre ambas ocupações intelectuais, tende a colocar a História não já como o "melhor conhecimento" senão como o "único conhecimento pussível".

Não consideraremos - é mais interessante estabelecer desde já - a conhecida afirmação de Aristóteles contida na Poética que expressa:

"Com efeito, a diferença entre poeta e historiador não está em que um escreva com matéria e o outro sem ela, que sendo possível reescrever Heródoto com métrica, com métrica ou sem ela, nem por isto deixaria de ser História. A diferença encontra-se no fato que um diz as coisas como se passaram e o outro como oxalá tivessem se passado" (1).

Não a consideramos em especial por ser anterior mesmo :o surgimento da Novela no munde antigo, não ter outros frutos da História para julgar que os do século $\mathrm{V}$ a. C. e porque essa situação que coloca a poesia como têrmo médio da Filosofia e da História, se explica dentru de uma valorização da Filosofia como conhecimento supremu e perfeito.

\section{Origens da História e du Novela.}

E' freqüente esquecer que a História nasce no tronco secular da epopéia assim como a Novela. Poderíamos dizer que surge quando se produz a crônica em que se objetiva o fato incerto da epopéia. Quando oferece um quadro verdadeiro do passado humano, cresce e se supera, elevando-se ao seu destino, fácilitando um esqueleto ou filosofia que representa -.- de acôrdo com as palavras de W. Dilthey - uma autognose do homem.

(1). - Aristóteles, Poética, Edị̧ăo bulíngae da Universidade Autónoma do México, 1945, IX, pág. 14. 
"A História como o drama e a novela - diz Toynbee - é filha da mitologia. Esta é uma forma particular de compreensão e de expressão de onde - do mesmo modo que os contos de fadas de que tanto gostam as crianças, e os sonhos dos adultos sofisticados - a linha de demarcação entre o real e a imaginação não foi traçada. Da Iliada, se disse, por exemplo, que aquêle que empreenda sua leitura como um relato histórico, ali encontrará a ficção e em troca, aquêle que a ler como uma lenda, ali encontrará a História". (A. J. Toynbee, Um estudo da história, Buenos Aires. Emecé, 1951, tomo I).

Mas, Clio não repete o milagre de Palas Atenas, surgindo do crânio de Zeus. Durante a Antigüidade e a Idade Média só excepcionalmente alcança as exigências pré-estabelecidas, isto numa evolução fecunda. da que

Quando surge oficialmente (digamos assim) Heródoto, ain-

"despojado da forma métrica, não abjura sua origem, nem a paixão pelo maravilhoso, nem a ingenuidade cândida e patriarcal do relato, que fazem do autor um poeta épico".

A auto-exigência da verdade a que se submetem em suas obras os grandes historiadores greco-romanos, os cronistas da Idade Média, certos autores renascentistas e os tratadistas dos Tempos Modernos, afirma a existência da História. Não constituem, porém, a expressão de um fenômeno geral. $U$ público procura na História, na maior parte das vêzes, material para a sua avidez de ficção.

"A História é uma Novela que entretém",

pode-se ouvir das pessoas de pouca cultura, e, um autor conhecido, Próspero Merimée, disse:

"Da História, gosto apenas das anedotas".

Não é necessário insistir nessa posição; porém nos interessa mostrar que também a Novela partilha de considerução paralela, pois corresponde a essa exigência única (2).

A Novela é um fruto tardio da Antigüidade. E'

"a última degenerescência da epopéia e não existia, não podia existir, na idade clássica das letras gregas".

(2). - Origenes de la Novela por Marcelino Menéndez y Pelayo. "Emecé. . Buenos Aires, 1945, pág. 14. As cltaçōes que se seguem correspondem às págs. 14, 15, 474 e 475 do tomo $I$. 
Surgiu da decadência extrema da literatura e se desenvolveu principalmente na época bizantina. Caracteriza-se pela

"ficção, pelo predomínio da fatasia" individual e pelo livre jôgo da imaginação criadora"

de acôrdo com as formas de individualização; mas, sua relação com a estética e, portanto, com a Literatura, é precária. Menéndez y Pelayo a quem seguimos, condiciona o acesso do gênero à Literatura, e suas palavras devem ser recordadus com referência às novelas da Antigüidade, assim como às que se produziram na Europa Ocidental até o Renascimento. O faz com as seguintes palavras:

"A novelà tem dois aspectos: um literário e outro que não o é. Pode e deve ser obra de arte pura, porém, em muitos casos não é mais que obra de puro passatempo, cujo valor estético pode ser infímo: Assim como a História (naturalmente referindo-se à crônica ingênua, anti-cientifica da época que, como disse Lord Acton, está separada da historiografia moderna pela mesma diferença que existe entre a astronomia antes e depois de Copérnico, (Nota do Autor), diziam os antigos, agradável escrita de qualquer modo, assim, também, a Novela atinge um dos seus fins, sem dúvida o menos elevado, quando excita e satisfaz o instinto de curiosidade, mesmo quando pueril" e acrescenta mais adiante: "A Novela arte é para muitos poucos; a Novela entretenimento está ao alcance de todos e é um gôzo lícito e humano mesmo quando de ordem muito inferior".

Para André Chastel:

"Assim como deve o seu nome (em francês) sem dúvida à civilização medieval e mais precisamente ao século : XIII deve, também, a Novela, seu primeiro valor fundamental, que consiste em representar a significação essencial da vida". Declara, judiciosamente, sem embargo que, "a Novela sempre existiu. Seu princípio é ativo em tôdas as composições narrativas que, para dar uma imagem do destino humano, propõem um mundo de aventuras, e de personagens ilusórias, divertidas e exemplares".

As ạiniones de Chastel sintetizam em certo sentido as de Marcelino Menéndez y Pelayo, e as do próprio Caillois.

Autores como Roger Caillois chegam a opinar que não se justifica o entrosamento da Novela com a Literatura, por

"não ser sua finalidade de ordem estética", 
afirmação inexata no que respeita ao gênero; mas, aplicável̂ às suas manifestações nos primeiros séculos de vida. Com efeito, os começos da Novela no mundo antigo - com as exceções louváveis de Apuleio e Petrônio - confirmam o acêrto da afirmação que não é desmentida pela floração novelística de Bizâncio, de valor estético quase nulo e cujas combinações imagina-. tivas no mundo das possibilidades aparecem em concreções tiradas da vida. A mesma observação cabe para as novelas de cavalaria, pastoris ou de aventuras prodigiosas, lidas na Europa. Digamos finalmente - para encerrar êste instante da história do pensamento em que se recorre indistintamente à História e à Novela para satisfazer a ansia de ficção - que Benedetto Croce considerou como a razão histórica dessa situação. Transcrevamos suas palavras:

"As idades em que se preparam reformas e trans-. formações, observan atentas o passado, ao qual querem despedaçar os fios para em seguida reatá-los e continuar tecendo-os. As idades consuetudinárias lentas e. pesadas preferem as fábulas $\mathrm{e}$ as novelas à História e reduzem esta mesma História a fábulas e novelas" (4).

A História, durante séculos, não supera a Antigüidade; mas, esmera-se na forma. Como um gênero a mais dentro da Literatura apresenta de modo formoso e em ocasiões eterno, a crônica dos sucessos passados, a vida dos príncipes e dos santos. Não é estranho que figure de forma modesta nas Universidades Ocidentais, incrustada no seio da Retórica.

Suas relações com os demais gêneros literários são ativas enquanto o permite a limitação do seu próprio campo, e se não se realiza de forma especial com a Novela, isso se deve ao divórcio em que esta vive, da Arte e da Vida. Apesar do famoso sarcasmo de Políbio, o teatro e a poesia extraem material da História, mas, por sua vez a História usa de todos os recursos literários e em ocasiōes com vantagem, para a tradição das Belas Artes. Recordemos os grandes historiadores do século XV ao XVII.

(3). - Concelorcorvo, por exemplo, inicia El lazarillo de ciegos caminantes dizendo: "Suposta, pois, a incerteza da Historia, torno a dizer, deve-se preferir a leitura e estudo da fábula, porque sendo ela parte de uma imaginação livre e desembaraçada, influi e deleita em maior grau". Pág. 24. Solar, Buerios A1res, 1942.

Naturalmente que se referia à crônica ingênua, anti-científica da época, como dissera Lord Acton, que está separada da historiografia moderna pela mesma diferença que exiște entre a astronomia antes e depois de Copérnico. (Nota do Autor).

(4). - La Historia cómo hazafia de la Iberdad, por Benedetto Croce, Méxicu, FCE 1942, pág. 46. 
Entretanto, o mérito é maior se tivermos presente que o historiador deve realizar sua obra literária sem falsear a verdade a seu alcance (5). E' justificada plenamente a grandeza dos pais da historiografia moderna: Petrarca, Bocaccio, Bruni, Maquiavel e Guicciardini. Também, justifica-se que um autor mais recente - Lord Macaulay -- tendo presente a plêiade de historiadores - artistas a quem admirava por sua "arte em relatar" tenha dito:

"A História começa pela Novela e termina pelo ensaio" requerendo ao historiador "bastante imaginação para dar à sua narrativa interêsse e colorido", pois conceitua esta disciplina como gênero eminentemente literário e artístico, como "parte da literatura" (6).

A Novela se fêz realista com Cervantes e ao crescer sua importância, cresce ao mesmo tempo sua vinculação à História que, entretanto, não chega a diferenciar-se da que esta tem com os demais gêneros literários. Temos que esperar o século XIX para ver uma transformação notável de ambas as disciplinas.

\section{A Novela e a História no século XIX.}

O século XIX foi chamado com justiça o "século da História" e não seria ousado chamá-lo também de "século da Novela".

Esta não podia permanecer indiferente a essa situação, pois está em sua essência mesma, como dizia Guyau, ser

"História condensada, documento, vida interior",

ou, como Ortega y Gasset completará mais tarde a

"necessidade em que se acha o novelista de tapar o' mundo real com seu mundo imaginário" (7).

(5). - Naturalmente êsse não é o caso dos autores como o Abade Vertot que quando oferecia nova documentação para corrigir a história de um cêrco replicou: "Mon siège est fait" e o do $P$. Courier que pouco se importava que Pompeu ganhasse a batalha de Farsalla "sl cela pouvalt arrondir tant soit peu la phrase". O fato de que esta classe de "historladores" gozasse de prestigio é outra demonstração do que estamos dizendo.

(6). - As citaçóes pertencem a Raul Montero Bustamante, La ciudad de los libros, Montevidéu, Ligu, 1944 (págs. 7 a 64), ensaio "Encuentro con Lord Macaulay".

(7). - Guyau, El arte desde el punto de vista soclológico, cap. I; Segunda parte, t. II, Montevidéu, Bertani, 1913;, "La novela pstcológlca dé nuestros dias". "Ideas sobre la novela" de Jose Ortega y Gasset inserta nas obras completas dêste autor, Madrf, 1932, págs. 930 e segs. Espasa Calpe. 
Já dissemos que a Novela havia cumprido as etäpas necessárias a que foi obrigada pelo seu destino e que justificam sua poșição especial na Literatura, pois,

"sem grandes preocupações teóricas, permite-se tôda a liberdade, ensaia tôdas as audácias, aumenta seus domínios e ambições sempre mais, se enriquece com naturalidade a custa do que as outras artes perdem; depreciam, abandonam ou disperdiçam. Quase poder-se-ia dizer que a literatura não lhe é suficiente: se apossa da ciência, desdenha limitar-se à ficção, empreende a descriçãn do real, e está pronta sua explicação ou melhor dizendo seu desenvolvimento". (8).

Nos fins do século XVIII, a Novela foi filosófica e quase nos primeiros anos do século XIX será histórica. Finalmente, e tornando em parte ao que já foi dito mais acima, no "século das luzes" o homem pensava filosòficamente, e, no século XIX c fará històricamunte.

Em 1802, Chateaubriand publicou O Gênio do Cristianismo, e mais tarde, Os Mártirés; enquanto que na Inglaterra, Walter Scott dá a conhecer em 1820 sua novela Ivanhoe. Havia surgido um novo gênero, o da novela histórica na qual Maigron indicava as seguintes características:

"informação histórica, côr local, exotismo; tendo presente o exterior, sacrificando algo do interior, evocação das civilizações longínqüas e de sociedades diferentes ou desaparecidas; apresentando o passado como caduco; sentimentos não individuais, senão genéricos e representativos da coletividade: tipos, indivíduos; a história central, como tragédia e epopéia, não é inventada".

Disse Menéndez y Pelayo a respeito do próprio Walter Scott:

"soube combinar o espírito da poesia cavaleiresca, a advinhação arqueológica, com a nostalgia das coisas passadas e com a observação realista dos cóstumes tradicionais próximos a perecer" (9).

O êxito obtido pelo escritor escocês foi simplesmente prodigioso. Imitado em tôda a Europa e América, seu estilo foi utilizado por Fenimore Cooper (nos Estados Unidos), por Alexander Bronikovski na Polônia, por Willibald Alexis, Wilhem Hauff, Ludwig Tieck, Gottfried Keller e Immermann nos paí-

(8). - Roger Caillois, Sociologia de la Novela, Buenos Aíres, 1942, pág. 15

(9). - Marcelino. Menéndez y Pelayo, ob. cit.; tomo I, pág. 478. Veja-se Montero Bustamante, ob. cit., pág. 127. 
ses germânicos; na França, onde foi traduzido em 1816 (obscurecendo um pouco a glória de Chateaubriand), escreveram novelas históricas seguindo seu estilo: Alfred de Vigny, Merimée, Balzac, Victor Hugo e Dumas (êstes dois últimos foram seus tradutores em francês); na Itália não só é imitado como também surge um autor da estatura de Manzoni, de cujas novelas foram tirados argumentos para libretos das óperas de Rossini, Puccini, Donizetti; é, finalmente, nos países de língua espanhola, que atinge o áuge tardiamente (10) mas, permanece mesmo quando o autor de Ivanhoe já está esquecido no resto da Europa. Colaboraram na emprêsa: Larra, Espronceda, Martinez de la Rosa, Gómez de Avellaneda, Manuel de Jesus Galván, Cánovas del Castillo, Castellar, José Ramon Yepes, Navarro Villoslada, Vicente Fidel López e Carlos Reyles.

A crítica mais reputada da época consagrou Scott como o maior dos novelistas (hábil mago, segundo Hugo), correram lendas sôbre a sua pessoa, afirmando-se, por exemplo, que sob o seu nome trabalhava e publicava trabalhos uma equipe de eruditos... Não é estranho que a Novela histórica, entronizada em êxito editorial, pretendesse ser mais verdadeira que a própria História. Foi uma pretensão suicida, pois a jovem ciência histórica provou suas novas armas contra Scott e seus exígonos mostrando seus erros, irreverências, e até o desconhecimento das épocas que pretendia reviver. Para completar o desastre, a novela histórica foi também atacada no camfo literário, fazendo-lhe censura inversa; quer dizer o seu suposto desprêzo pelo estético em benefício do histórico (Goethe, Heredia e até Manzoni).

Amado Alonso, vendo a queda da novela histórica romântica não pôdé deixar de dizer:

"está em crise quase desde o seu nascimento" (11).

Sucede que o romântico, por seu temperamento pitoresco e apaixonado dedica-se à exumação de certos temas históricos, mas, nos casos de conflito, prëfere sempre a "verdade poética" à "verdade histórica".

(10). - Guillermo Zellers em La novela histórica en España 1828-1850, Nova York, 1938, confirma o fato, porém, no prefácio diz que "os elementos de ficção e história em conjunto se encontram nas epopéias, nas crônicas, nas traduçōes de lendas arabes e outras orientais, nos contos de cavalaria de fundo histórico e numas poucas obras às quats pode-se aplicar corretamente o nome de "novelas historicas". O esclarecimento é discutivel e encontra-se negado expressamente na ob. cit. de Menéndez y Pelayo.

(11). - Amado Alonso, Ensaio sobre la novela historica. El modernismo en la gloria de Don Ramiro. Faculdade de Filosofia e Letras, Buenos Aires, 1942, pág. 73 . 
A crítica combinada da Ciência Histórica e da crítica literária foi tão eficaz, que Manzoni publica em 1827 Os noivos - obra tècnicamente superior às de Scott - apontando que o leitor de novelas históricas tem "só atenção para a história" e sustenta a impossibilidade literária do gênero.

Essa situação espiritual em que se coloca o novelista romântico é uma auto-suficiência explicável da novel Ciência Histórica que esclarece que se entenda a Novela e a Historiografia como duas coisas, não só separadas, mas que também rão podem encontrar-se. Não olvidemos que estamos na época dos eruditos alemães e que a História, salvo uma relação grandemente militante com as Ciências Políticas, entende seu labor sòmente como investigação de fatos e estudo de fontes documentais. Se, como assinalamos, a primeira interpretação da História, como ficção, se perpetua no conceito popular e a correspondente à definição da História como gênero literário em núcleos de pessoas cultas que reunem o gôsto da beleza ao interêsse pela História; esta terceira interpretação se mantém mesmo entre os historioradores de profissão.

Apressemo-nos em dizer, que nem êste "esplêndido isolamento" da História foi duradouro e que nem tudo o que trouxe a novela histórica foram males.

Produzido o encôntro entre ambas ocupações intelectuais, seu destino se enlaça, em graus diversos, e para sempre, a História mesma sente a influência da novelística romântica.

Segundo Gooch, quando perguntaram a Dumas qual era a causa do extraordinário êxito que acolheu a História dos Girondinos de Lamartine, disse êste:

$$
\begin{aligned}
& \text { "é porque a História fỏi elevada ao nivel da Nove- } \\
& \text { la" (12). }
\end{aligned}
$$

Uma página famosa de Thierry, traz o reconhecimento do famoso historiador francês a que Os Mártires e Ivanhoe atingiram os seus fins ao demonstrar

"que o passado não estava morto e que seus participantes eram homens com paixões iguais às nossas".

Ranke se afirmou em sua vocação e por oposição criou tôda uma escola, partindo também daquele êxito literário.

No entanto, a História prossegue ampliando-se. Discutida ras obras de Riehl, Freytag e Buchkardt, a História da Cultura é uma conquista definitiva da investigação histórica do sé-

(12). - Historia e Historiadores del siglo XIX, Méxíco, FCE, 1942, pág. 234. 
culó XIX que se propõe a partir daí à análise das criações culturais da sociedade humana em seu conjunto. À simples busca de fatos do passado, junta-se uma reconstituição simbólica, a materialização do espírito de uma idade passada que faz com que Schlegel classifique o historiador como "profeta ao revés". Esclareçamos que não se trata de imaginação literária, senão que estamos ante ao que Goethe chamava "imaginação para a verdade do real" e que Croce, reagindo expressamente contra a confusão, disse

"a faculdade cuja presença observam - os historiadores - em seus labores, não é a fantasia dos poetas mas a imaginação combinada das diversas potências, sempre distingüidas pela melhor estética e a melhor crítica de arte". (13).

Nos meados do século passado, destacam-se historiadores que escrevem literalmente suas conclusões. A História depois de enriquecer seu acêrvo parece volver ao seio da Literatura. Essa volta é mais aparente que real. Dado seu volume, transcendência e personalidade, permanecerá sempre independente e cada vez mais expansiva, porém utilizará elementos literários. Em alguns círculos o tema fixou-se eqüivocamente na pergunta: é a História Ciência ru Arté?

Burckhardt, justificando sua bela opinião, diz:

"Para mim a História é, em grande parte, poesia; constitui-se de uma série das mais belas e pitorescas composições".

Carlyle, algum tempo antes, mostrava-se mais preciso, afirmando o esclarecimento sôbre a suposta "filha pródiga".

"Considere-se tudo que se encerra nesta só palavra: passado! Que significado tão patético, tão sagrado, tão poético, está, em todos os sentidos, nela implicado! Um significado que vai tornando-se mais evidente quanto mais retrocedemos no tempo, quanto maior é a quantidade dêsse mesmo passado através do qual temos que olhar! Enfim, a História é a própria poesía. E, a realidade se interpretada corretamente é maior que a ficção" (14).

Por outro lado, excluindo-se a primeira etapa do reduto erudito e o que chamamos de esplêndido isolamento, a Histó-

(13). - Croce, ob. clt., pág. 141.

(14). - Citado de acôrdo com a Introdução (pág. 13) da Hístória Social da Inglaterra de George Macaulay Trevelyañ. México, FCE, 1946. 
ria pede à Fílosofia um esquema de idéias ou interpretações, a : Filosofia da História, como é conhecida na história do pensamento. Referimo-nos à entrada definitiva das idéias interpretátivas filosóficas no seio da Ciência Histórica, que vinha de se realizar recentemente no século XIX. Em parte, como conseqüência dêste fato, foi a obrigação da História de pronunciar-se sôbre $o$ passado, oferecendo um juízo e inclusive adiantando uma opinião sôbre o futuro imediato. E' muito útil consultar a crítica que Croce faz a Ranke e os pontos de vista que expõe sôbre a razão de ser da História baseando-se quase exclusivamente nesta exigência, na obra que estamos citando.

Ainda que contingente, é claro que a História apóia-se na Filosofia com a mesma utilidade com que recorre à Literatura. Por isso nos seduz a imagem usada por Karl Vossler ao falar di História cultural:

\begin{abstract}
"Porque nestes dois pilares, na arte e na filosofia; apóia-se em igual medida a abóbada da História. Na pedra clave dêste arco, na instância documental, convergem por ambos os lados os suportes, assim como de sua parte, a clave descarrega seu pêso de um e de outro lado" (15).
\end{abstract}

A êste momento das relações da História com a Literatura corresponde o período da novela histórica do naturalismo. Tratada com ingratidão e até com dureza, a Novela, entretanto, não se havia separado da História. Obras como as de Gustavo Flaubert, Sienkiewiecz, León Tolstoi, Bulwer, Lytton, Wallace, Pérez Galdés, e outros novelistas e já no nosso século Merejkovsky, Roth, Kesten, Aldanov, T. Mann, C. Wiseman, Anatole France, Pierre Louys e na América, Sandburg, Crane, Cather, Hudson, Arthur Koestler, Howard Fast, Thornton Wilder, Thomas H. Costain, J. R. Parkins, M. Jagendorf, L. Feutchwanger, Jean Anzanet, Acevedo Diaz e Enrique Larreta.

"Ao fortalecer o sentido realista, cresce a armação erudita que se faz professoral" -

disse Amado Alonso, que entende estarmos ante uma transformação total da novela histórica antiga - pois

"a atitude informativa desaloja - na obra do naturalismo - ou perturba a ação criadora".

(15) . - Karl Vossler, Filosofía del Lenguaje. Ensayos. Losada, Buenos Aires, 1943, pág. 84. O ensaio de Vossler difere, em linhas gerais, do que sustentamos em diversos pontos. 
Deve-se anotar, também, a mudança de posição do autor literário, como no caso famoso da polêmica Flaubert-Sainte Beuve. Antes da sua elaboração artística o primeiro dêstes munira-se de informações eruditas sôbre a civilização cartaginesa que assombraram mesmo aos especialistas. Mas, a relação entre a História e a Novela, implícita na definição de Vossler, não se concretiza sòmente na novela histórico-naturalista, mas, encontramos que a evolução da Novela no século XIX se aproxima da História e com o desenvolvimento desta faz coincidentes certos aspectos com a ficção novelesca.

Esta, durante o século XIX, sofre uma evolução assombrosa, um desenvolvimento em essência e em quantidade sem paralelo com os demais gêneros literários.

No século XVII, Descartes tinha uma consideração depreciativa da História; um século antes, Montaigne não cita novelas entre suas leituras, porém, ninguém no século XIX podia considerar-se culto desconhecendo a História, nem tampouco podia ignorar o lugar da Novela no seio da Literatura. Os autores mais ilustres cultivam o gênero e sua influência se faz sentir na poesia e no teatro.

"A novela estende-se, engloba pouco a pouco tôda a literatura, a assimila tôda", diz Caillois e acrescenta: "Sua ambição não conhece limites. Não há ciência que não veja seus últimos. trabalhos saqueados... Nem sempre trata-se de simples vulgarizaçōes. O novelista propõe-se realmente a escrever História, psicologia, sociologia e a maior parte das ciências devem-lhe muito".

A causa da História que também existe, se fêz, cremos, não quando o novelista crê fazer História( que seria o caso da novela histórica), ou da biografia novelada, senão quando extrai da sociedade de onde se transcorre sua existência o material de sua obra. O balanço desta colaboração, durante os últimos cem anos, já efetuado com respeito à psicologia - citemos Proust e Joyce - ainda está por realizar-se com relação à História, assim como também está por fazer-se a edição crítica das novelas históricas, útil ao leitor não especialista.

O sucesso não muito grande alcançado por êste último gênero é devido à uma transformação da História mesma que tornou esta parte da literatura desnecessária, e por outra parte têm surgido várias formas novelísticas que atendem

"a atração que a Hịstória exerce sôbre um : público cada vez maior" o que em última análise "trata-se de 
um contágio da curiosidade novelística em domínios que pareciam lhe estar vedados"

como diz o mesmo Caillois.

Em primeiro lugar a novela moderna tem como tema - e risto cremos reside a maior razão do seu êxito - a vida humana verossímil

"a existência do homem na sociedade e sua consciência dos deveres impostos pelo caráter social da existência" e talvez isto, em última instância, responda ao desêjo do público leitor "que exige que a novela seja viva" (16).

Partindo de outro plano, Amado Alonso nos diz o mesmo.

"A novela é um modo de literatura que ao entrar no século XIX atende de maneira especial ao mundo material e cultural de onde provém as individualidades descritas" (17).

Sob o título definidor de A história da literatura começa a ser História, Julian Marias reclama recentemente uma atitude com vistas à História no tratamento dêsse gênero e cita como exemplo o livro de Montesino sôbre a novela espanhola no século XIX. O argumento dêste autor é que a novela é uma conseqüência do advento e constituição de uma burguesia nacional, $€$ por isso sòmente na segunda metade do século passado apareceu na Espanha a grande novela local (18).

A definição de Saint Real segundo a qual "A novela é um espêlho que se estende ao largo de uma caminho" começa a ser exata.

Para escrever a História de nosso mundo contemporâneo, será necessário recorrer do mesmo modo à análise dos arquivos e aos fatos materiais contidos na literatura da época, dentro desta, da Novela em especial. Apressamo-nos a destacar que a evolução pormenorizada da Novela, mesmo quanto também sofrida pelos outros gêneros literários, só é completa nesta. Na poesia, por exemplo, enquanto a Novela se apega à vida real, sustenta-se absurdos históricos como "a arte pela arte" ou "a poesia pura".

Com Balzac e num certo sentido com Zola, a novelística, crê, entretanto, apontar a eterna "comédia humana". (colocando-se no plano transcendente da filosofia do século XVIII), po-

(16). - Calllols, ob. cft., pag. 119.

(17). - Ob. cit., pág. 45.

(18). - Em La Nacíon, Buenos Aires, 5 de fevereiro de 1956. 
rém, com Anatole France, já se denomina "história contemporânea".

$\mathrm{Na}$ grande literatura francesa, cujos passos estamos seguindo nos últimos parágrafos, a Novela atinge seu cume com as chamadas "novelas-rios" em que atuam milhares de criaturas de ficção que participam, se desenvolvem e se explicam na realidade contemporânea daquele país. Tal como sucede em Jean Christophe de Romain Rolland, Os homens de boa vontade, de Iules Romain; Os'Thibault, de Martin Dü Gard, e Os caminhos ca liberdade de Jean Paul Sartre (19) .

Finalmente, o novelista para obter seus personagens tem três métodos possíveis. Primeiro, utilizar personagens reais e até famosos (nas obras citadas de Rolland e Du Gard atuam entre outros: Jaurés, Pio X, Benito Mussolini e Joffre) e como sucede em Contraponto de Huxley, vários famosos intelectuais, seu amigos, como D. H. Lawrence mal disfarçado pelo nome de Rampion (20).

A segunda possibilidade é a de criar um ser novo, inexistente, combinando observações minuciosas da realidade circundante 'como' disse Dostoievsky, pondo em circulação

$$
\text { dos na vida"; }
$$

na novela russa ficaram famosos, conseguidos por êste método, o Oblomov, Goncharov e Podkolyoyosin de Gogol. Naturalmente, o próprio Dostoievsky cunhou para a eternidade personagens obtidos' por êste meio, com freqüência

"gente vulgar que é a todos os momentos a chave e o ponto essencial no encadeamento dos assuntos humanos. rer ao

Por fim, a última fonte de que o novelista dispõe é recor-

"seu próprio caráter, ao seu próprio destino" nascendo assim "a novela inconfessadamente autobiográfica e que constitui uma modalidade intermediária entre a ficção e a história"

conforme J. L. Sánchez Trincado, de quem nos valemos das idéias (21). À parte as memórias e confissões, de êxito tão

(19). - Nos n. ${ }^{\circ}$ 8, 10;" i1 e 12 da revista "L'age Nouveau", Paris, há uma interes: șante polếmịca sôbre êste tema entre M. Fabri e G. Dutraniel.

(20). - Dostólevsky, o idiota. Buenos Aíres, Emecé, 1945, tomo II.

(21). - J. L. Stánchez - Trincado, Leyenda, Historla y Mito. Caracas, Elite, -.1944, pág. 15. Este pensamento nos parece na verdade exato, ainda quando seguimos êste autor na análise das possibilidades do novelista para. criar: personagens. 
marcante, e onde o autor se confessa em público usando seu próprio nome ou o semi-obscurecendo através de um personagem suposto (como sucede, por exemplo, com León Tolstöi; em outras ocasiões, autores não têm vacilado mesmo em se retratar por um personagem feminino (Madame Bovary, sou eu, disse Flaubert), ou por intermédio do personagem "mau" da obra, como Pérez de Ayala em A pata da raposa.

Há ocasiões em que o escritor utiliza não a sua personalidade autêntica, mas ao que Freud chamou seu "eu ideal", quer dizer sua personagem sublimada nas aspirações que contém e que realizou. Maurois em Aspectos da biografia refere-se extensamente à esta situação na obra de muitos novelistas que pode desviar o leitor do verdadeiro perfil do autor (22).

Para finalizar, em qualquer dêstes três casos, o personagem brotou da sociedade viva da época, sofrerá de suas restrições e será glorioso com sua grandeza. A Novela quase que se fundiu com a sociedade que difunde, que reflete, perpetuando-a numa ambição comum com o documento histórico. Isto ficará melhor explicado se tivermos presente que cada INovela contemporấnea leva incrustada uma interpretação da vidà ou seja uma filosofia da História. Este fato passa desperçbido para o leitor comum, mas surge evidente para àquêle que está familiarizado com os conceitos das ciências sociais e da filosofia. Em algumas ocasiões o novelista preconiza abertamente uma interpretação. Político-social na novelística revolucionária, católica militante em Bloy e Chesterton, ética em Malraux (quando não é político-social), partidária de uma renovação das idéias sexuais em Lawrence, etc. Outras vêzes, está implícita na obra de forma difusa. Mas, a crença na divindade, na sexualidade, nas formas de produção, a ânsia do poaer, a vontade humana ou qualquer outra visão especial como motores da existência, e por tanto do porvir histórico, estão sempre presentes na obra literária. E' possível seguir na Novela dos últimos cem anos, a evolução sofrida por qualquer idéia entre os membros de um círculo determinado.

$\mathrm{Na}$ Novela dos nossos dias pode-se, inclusive, perceber o ideal humano do momento em que a obra é concebida. A mes-

(22). - André Maurois, Aspectos de la Biografía. Santiago do Chile, Ercilla, 1937, págs. 85 a 91 sôbre os excessos de se procurar o autor no protagonista. Sôbre a difícil fronteira existente entre as duas interpretações anotadas. resulta aspecto pitoresco - porque prolonga o eqüívoco em que stendhal vi. veu sua própria vida - como difere a interpretação de Maurois (pág. 90) e a de Georg Brandés em Las grandes corrientes de la literatura del siglo XIX. Buenos Aires, Americalee, 1946, T. II. 
ma variação que observamos na História para apresentar as grandes figuras, pode-se ver na Novela por intermédio da figura do "herói". Desde o jovem que padece do le mal du siècle de Musset aos personagens do norte-americano James Cain, há uma verdadeira galeria de heróis que constituem o espêlho da época. Muito a miúdo, a sua existência, ainda que fictícia, é oferecida como autêntica "vida exemplar". A intenção de Rolland é transparente a êsse respeito, e seria bem fácil fazer uma lista de autores inspirados em fim moralizador sobreposto $\therefore$ criação literária.

"A Novela - nos diz Caillois - coloca frente à sociedade cuja decomposição descreve, heróis que com seu exemplo e com suas virtudes públicas e privadas, a convidam a recuperar certa coesão".

Outro ponto que caracteriza a novela de nossa época é a análise dãs relações da natureza e do ambiente com o homem. Percebe-se o grande progresso feito pela Novela dêste tipo quando se recorda a visão da natureza em Dafnis e Cloe e Paulo e Virgínia, por exemplo, e se as compara com a novela iberoamericana (especialmente Gallegos, Rivera, Amado, Cerruto, e Icaza). O ambiente, nem é necessário insistir nistó, pois na novela moderna a sua presença é até exagerada, havendo ocasiões em que se apossa da obra inteira.

A realidade aparece na novela contemporânea, não só através de suas formas exteriores, como sucede por exemplo em Zolá, e seus continuadores, mas o novelista procura surpreender o homem em tôda sua integridade intelectual e psíquica. "Do realismo à introspecção", assim chama Luís A. Sanchez, a. essa evolução produzida na novela de nossos dias. A análise da vida espiritual mostrando como as personalidades monofacetadas da literatura eram uma simplificação do artista e uma incapacidade para observar, desapareceram. Os autores do século passado que recobraram interêsse para os leitores de nossos dias, porque correspondem a essa linha, são Stendhal e Dostoiewsky que conhecem uma nova e fecunda primavera. Sánchez na obra citada resume o que chama seus

"fatôres inéditos: introspecção, realidade interna sôbre a anedota externa, beligerância da anormalidade, aparição da subconsciência" (23).

(23). - Lufs A. Sánchez, Panorama de la Literatura actual. Ercilla, Santiago do Chile, 1936, pág. 30. 
O tema eterno, porém sempre novo, da contemplação estética do personagem humano, adquiriu uma dimensão inédita. O elemento fundamental da Novela deixa de ser a ação imaginada para converter-se em visão de uma personalidade. Ortega y Gasset o expressa ao dizer

"Nosso interêsse transferiu-se da trama às figuras, dos atos às pessoas",

e noutra passagem de sua obra atreve-se a vaticinar: "Não na invenção de "açōes", mas na invenção de "almas" interessantes está o melhor futuro do gênero novelístico. A melhor prova disto, está na decadência do folhetim - pródigo em ações de máscaras inumanas - e no êxito de Proust, onde a ação que é minima confunde-se com o sonho em benefício de um só protagonista: a memória.

Não é exagerado acompanhar Sánchez-Trincado na afirmação de que a Novela pretende - como o fêz a Filosofia e a própria História -

"Explicar ao homem em seu mundo, encontrar a correlação existente entre as figuras humanas e co contôrno cultural que as esculpe e que se deixa modelar por ela" (24).

Quase sempre êsses elementos, que caracterizam a Novela a nosso ver, aparecem separados, impressos em ocasiões, cada um dêles, numa obra particular. Ocorre pensar que além dos seus méritos literários intrínsecos, explica-se a grandeza de A Montanha Mágica de Thomas Mann - que Edmond Jaloux qualifica como "a melhor novela do século XX" - pelo fato de reunir em seu seio todos os elementos anotados com uma riqueza e profundidade inimitáveis. Há um herói de "nosso tempo" na pessoa de Hans Castorp, há uma análise notável das relações homem-natureza, e de seu gêmeo homem-ambiente, em vez de uma filosofia da História, há várias (Settembrini, Naphta, Peeperkorn, Krokovski, Joachim e até Mad. Chauchat, têm sua interpretação dos fatos). Os personagens aparecem em tôda sua complexidade psicologica. Além do mais, deve-se computar o núcleo de idéias do próprio Mann que não se compromete com suas criaturas de ficção e plasma tôda uma concepção - perfeitamente histórica - sôbre o Tempo, a Morte e a . Vida, a enfermidade, etc.

(24). - Ob. cit., p;g. 25. 
Depreende-se da obra - sem necessidade de recorrer aos. biógrafos para confirmá-lo - que é inspirada por uma experiência pessoal direta.

Relembrändo-se obras como A Metamorfose de Kafka po: de-se duvidar da evolução e características da novelística mo-. derna, tal como a esboçamos. O original em Kafka, é definitivamente o elemento que tende a desconcertar, é sua capacidade inigualável de inventar, mas, sua obra inteira, com seu conceito do homem, a presença de sua biografia em seus livros, sua visão mesma teológica, confirma que o escritor chéco não. desmente o que foi dito anteriormente. Jorge Luís Borges que não pode ser suspeito de historicismo - o confirma no prólngo da edição argentina de A Metamorfose.

"Os fatos imaginados pertencem ao mundo real do mesmo modo que paus e pedras" (25).

Há, também, a afirmação do sociólogo americano contemporâneo Lewis Munford que diz em A Cultura das cidades:

Tudo leva a crer que em seu futuro próximo a Novela não só se desviará do entroncamento com a vida social, como o aumentará.

\section{Biografia e Novela Histórica.}

No século XX aumenta a importância da História. Por ser: uma época em crise como a que causou o seu ressurgimento como Ciência, e bem diferente das "idades consuetudinárias, lentas e pesadas" de quie fala Croce, nosso século

"não concebe outro conhecimento que o histórico, é u'ma época que não admite que possa compreender e explicar a si mesma senão através do seu passado e em. sua função de sua História. Do mesmo modo que um individuo que busca conhecer-se investiga seu passado, a humanidade interroga a História" (26).

"Por todo o mundo a produção histórica, também o diz Huizinga - é mais abundante que nunca. Distingue-se das demais produções científicas pelo fato de em nenhum outro terreno a produção ser feita para um público tão grandé. ' $E^{\prime}$ o privilégio e o caro dever da História o fazer-se compreender de tôdas as pessoas cultas. Cada ciência, procura em um certo grau ministrar

(25). - Lewis Munford, La cultura de las ciudades. Buenos Aires, Emecé, 1945, tomo III, pág. 28.

(26). - Do trabalho de A. Koyré, Philosophie de l'histoire, contendo o estado atual dos estudos históricos publicado em Paris in revista Europe n.0 9, setem. bro de 1946, Paris, págs. 109 a 117. 
um produto também para o uso popular.: Para as outras ciências continua a ser um subproduto. Para a História, é uma parte essencial de sua atividade" (27).

Esta intensa produção e a necessidade cada dia mais exigente do conhecimento histórico, como ingrediente central da Cultura, produziu, até o momento presente, um fenômeno similar 2o ocorrido nos princípios do século passado. A Literatura, ou mais concretamente a Novela, começa a utilizar o material histórico no terreno da biografia, de forma semelhante à usada para reconstruir épocas nos começos do século passado:

A biografia havia sido desde Plutarco um gênero histórico. No esquema historiográfico do mundo antigo quase se confuncia com a História em geral. Que resta da historiografia referente à Macedônia excluindo-se todos os elementos biográficos cáracterísticos correspondentes a Filipe e Alexandre? (28) . Em linhas gerais, na evolução que alcança os nossos dias, fora seu caráter fundamentalmente histórico, poderia ser caracterizada por seu espírito apologético e por seus valores estéticos. O primeiro está presente até no título da obra de Plutarco. As penalidades focalizadas aparecem como altos exemplos de vida e de ação. Sua criação conta-se entre as obras de positivo valor artístico produzidas pela História. Recordemos Vasari, Macaulay, Carlyle, Burckhardt...

A existência dêsses elementos apologéticos e artísticos, tão claramente assinalada, na época da polêmica " $E$ ' a História, Arte ou Ciência?" trouxe a dúvida sôbre a sua inserção nas Ciências Históricas, sendo alguns autores impulsionados pelo prurido de pureza clássica que ainda que bem intencionado era bem estreito mentalmente.

Dilthey resolvia o problema dizendo:

"As opiniões dos historiadores àcêrca do caráter científico da biografia acham-se divididas: a questão de que se deverá subordiná-la à História, fazendo parte da mesma, ou se corresponderá a um lugar independente na conexão científico-espiritual, é, em última análise, questão de palavras, pois, a solução depende do sentido que se dê à expressão ciência histórica" (29).

(27). - Ob. cit., págs. 30, 64 e 74 .

(28), - Windelband chega a diferenciar a ciência natural da História dizendo que aquela busca leis e esta figuras. Dêste modo a História seria uma soma de biografias. Cita H. Rickert, Ciencia cultural y ciencia natural. Buenos Aires, 1943, pág. 130. Espasa.

(29). - Wilhelm Dilthey, El mundo hist6rico. México, FCE, 1944, pág. 271. 
Os continuadores dos biógrafos já citados exageraram o sentido de exemplo contido na vida de seus personagens e como expressa Virgínia Woolf:

"O biógrafo vitoriano é dominado pela idéia de virtude. A estátua é sempre maior que o modêlo".

Assim, as biografias dos historiadores não agradavam por sua falta de realidade.

Por essa brecha lançou-se a novelística à conquista da biografia. Utilizou todos seus progressos, mostrados anteriormente no tratamento dos personagens históricos, como havia feito com os de ficção. A psicologia, o uso da introspecção, e o colocarse o personagem como "homem real", irmão da inquietação do homem contemporâneo, caracterizam, de acôrdo com Maurois, a biografia moderna (30). Na Inglaterra onde o gênero sempre teve cultores entusiastas, é Lytton Strachey o iniciador da chamada biografia moderna que logo foi denominada biografia novelada. Sua enorme difusão, já que se encontra entre a literatura mais popular, não lhe permitiu excusar-se de justificação. Seu ápice encontra-se na análise dos problemas típicos já enfrentados e resolvidos pelos historiadores precedentes (especialmente a disjunção História-Ética-Estética). Mas, procura fundar em razões lógicas a independência da Biografia da História, com sua inserção correlativa na arte, elevando-a em algumàs ocasiões a uma forma espiritual independente. Marcel Schowb tentava realizar a primeira dizendo que

"Os biógrafos - refere-se aos historiadores - supuseram que só a vida dos grandes homens podem interessar. A arte é estranha a tais considerações".

Sánchez-Trincado dizia na obra citada:

"A História conta a vida pública dos homens públicos, candidatos a personagens históricos, a novela e o drama restringem-se ao relato dos fatos da vida privada dos sêres simples" (31).

Ainda que certa esta aspiração - à qual opõe-se Maurois de forma expressa por razões de documentação - a História já abraçou a apresentação dos "sêres simples". Carlyle fêz uma grande biografia de um desconhecido, John Sterling e temos obras contemporâneas de História Social entre às quais devemos destacar: Gente da Idade Média de Eileen Power e Vida 
cotidiana dos romanos de Carcopino que tratam da existências de pessoas sem destaque.

Além disso, o próprio Sánchez-Trincado, reconhece em sua. exposição que

"o historiador moderno sente a tentação de imiscuir-se na vida recolhida e secreta de seus personagens".

Por intermédio justamente da História, sabemos hoje intimidades que alteram conceitos que pareciam imutáveis a respeito de personagens grandes e modestos.

Maurois crê que há um mérito em

$$
\text { ga: "Strachey - nas suas obrás - não critica, não jul-. }
$$

porém, isso já havia feito Ranke e de um modo mais original.. O mesmo escritor diz:

"Não é preciso que o biógrafo queira julgar ao historiador em demasia... Aquêle se propõe à pintura do. indivíduo e êste a ciência do geral" (32);

Dilthey já havia esclarecido êste ponto quando dizia:

"A tarefa do biógrafo consiste em compreender, com. base em documentos, o nexo efetivo no qual um individuo é dominado por seu meio e reage contra êle. Tôda: História tem que procurar nexos efetivos. O historiador penetra mais profundamente na estrutura do mundo histórico ao distinguir os diversos nexos e estudar sua vida" (33).

E' de notar que Maurois crê que na biografia pode haver Ciência e pode haver Arte; porém não deduz disso que se trata de um gênero histórico mas, que estamos na presença de uma categoria especial e independente (34).

Toynbee era de opinião que

$$
\begin{aligned}
& \text { "os fatos da vida humana... como os relativos à : } \\
& \text { vida privada dos sêres humanos" }
\end{aligned}
$$

estão à margem da História, e indica títulos de várias biografias: conhecidas para ilustrar sua assertiva.

Toynbee, porém, não pode ser considerado um historiadortípico. Ao fazer essas afirmações o faz mais como filósofo da. história ou sociólogo.

(32). - Maurois, ob. cit., pág. 105.

(33). - Ob. cit., pág. 271.

(34). - S6́bre a Imagem pitoresca que tem Maurois sôbre o conhecimento histórico pode-se consultar as págs. 95, 98 e 105 da ob. cit. 
Tanto é assim, que o seu mais ilustre comentarista em língua espanhola, Alfonso Reyes, diz:

"A biografia é gênero anômalo, apenas relativamente histórico. Alguns dizem que é por essência extrahistórico. Não exageremos: é extra-histónico por definiçấo convencional da História. Quem o quiser considerar virtualmente incorporado à História nem assim invalidará as conclusões que aspiramos. Gênero comparável ao retrato, é arte, e também documento. Histórico pelo giro mental, porém prêso por seu assunto às vidas particulares, como a literatura" (35).

A biografia novelada encontrando-se no pedestal de seus èxitos de livraria, pretende, como o fêz há cem anos a novela histórica, ser mais exáta que a própria História.

"Surge a biografia atual que é mais Novela que a História, e por isso mesmo é muito mais História que a chamada História"

chega a dizer Luís A. Sánchez e acrescenta entretanto:

"A Novela pilha a História, e isto também acontece com respeito às biografias. A História procura a Literatura, porque a História é vida, já que, dentro do dilema spengleriano se opõe à natureza. A História e a Novela são o mesmo quando se sustentam na vida. A Novela encontra a seu dispor uma nova fonte: a História. Já não como reconstrução como o fêz Sienkiewicz, nem como mistificação voluntária como o fêz Dumas, mas, como re-criação" (36).

Contra estas pretensões, como outrora, e efetuando uma crítica demolidora ouve-se a voz dos historiadores. Huizinga, sempre ponderado, refere-se a êsse ponto, enèrgicamente, com estas linhas:

"A segunda forma da História em luxação sobrecarrega o elemento fantástico da História, indispensável por si mesmo, e isto representa o exagêro do momento narrativo. Aludo à chamada histoire romancée. Note-se bem, não à novela histórica.. A novela histórica, é um gênero literário irrepreensivel. Tira sua matéria da História, das imagens de um passado histórico determinado, porém, a oferece como literatura pura, sem a pretensão de que valha como verdade estrita, mesmo quando o

35). - El deslinde. Prolegómenos a la teoría literaria. México, FCE, 1944, pág. 71. 36). - Ob. cit., págs. 164 e 168. Victor Hugo dissera que as novelas de Balzac eram "mais históricas que Tácito e Suetônio...", cołsa parcialmente cerca. 
autor acredita que a sua apresentação, do ambiente histórico seja exata. A "história literária". de hoje, começa como a biografia ornada como a criaram $\mathbf{E}$. Ludwig e outros, pretende fazer História, porém o faz não só com 'um excesso de meios literários, senão também, e isto é importante - com uma intenção literária. Não importalhes a parte sóbria da verdade conhecida. : Suprem-na pormenores imaginados, de indole psicológica, com mais colorido local do que o permite a tradição. E' História perfumada. Essa gente ignora a resignação do nãó saber e o bom gôsto das coisas não ditas. Desestimam a imaginação do seu leitor; que bem pode acontecer sẹm tantos adornos. Contra isto, pode-se alegar que a procura dêste gênero prova, sem dúvida, a existência de uma ânsia de leituras históricas que a ciência não tem podido satiszafre. E' impossivel negar, mas, é necessärio indagar se êste interêsse pela História demasiadamente adornada não significa uma delibitação do juízo e uma desgenerescência do gôsto, uma indolência espiritual do público formado pelo cinema. Há um século atrás o público culto lia com gôsto Castelar, Macaulay e Ranke. Era ứ público muito menos numeroso, porém tinha sem dúvida um interêsse histórico muito mais genuíno" (37).

Os professôres inglêses e estadunidenses têm formulado listas de "biografias noveladas" com seriedade científica e anatematizaram o restante como pernicioso.

Em certas ocasiões essa luta converte-se em dúelo singular. Frente a um caso concreto um historiador quebra lanças pela verdade científica. Como aconteceu entre G. G. Coulton e o famoso novelista: $\dot{G}$. K. Chesterton da Inglaterra (38).

Dissemos no princípio que a tendência de construir uma síntese inclassificável de História e Novela esconde o progresso das Ciências Históricas que se tornaram imprescindíveis.

No entanto, a luta contra a biografia novelada que salientamos é útil. Deve mostrar-se em primeiro lugar a impossibilidade da síntese que seu rótulo quer sugerir Em segundo lugar a sua falta de futuro: Harold Nicholson, diz judiciosamente:

"Quisera sugerir, primeiro," que a concepção científica da biografia é inimiga da concepção literária, e que,

(37) - Ob. cit., .págs. 83-84.

(38). - Veja-se um resumo dos valores requerido pela História à Biográtia nä obra de Charles Oman, On The writing of history. Londres, 1939, cap. IV, págs. 56-75. O detaihe da polêmica Coulton-Chesterton está no ensalo interessantíssimo de $A$. Huxley, De los encantos de la historia $y$ el porvenir del pasado, que na página 99 da edição chilena de 1937 possui. Musica en Ia noche. 
'no porvir, a primeira matará a segunda. A ciência biográfica exigirá não sòmente os fatos, mas, todos os fatos. A arte biográfica requer que a representação dos fatos, seja só parcial ou artificial. A curiosidade científica, ao desenvolver-se, tornar-se-á insaciável. Nenhum poder de síntese, nenhuma maestria em apresentação poderá seguir seus passos. Prevejo, portanto, uma divergência completa".

A conseqüếncia prática que extrai Nicholson - extremamente valiosa por tratar-se de um biógrafo - é que nesta luta entre o conteúdo e a forma, se se tornar necessário sacrificar um dos dois, mais vale que seja a forma.

Realmente há só uma biografia: a histórica, que como tal pode utilizar todos os recursos legítimos da Literatura. A outra é simplesmente novela a propósito de temas reais, sem outro mérito que procurar o simples deleite do leitor. Croce em 1938, em face a tais excessos, dizia:

“A biografia séria, mesmo assim, cairá sempre em um dós quatro tipos de obra que mais acima diferenciamos e definimos; ou são memórias da existência de um individuo, quer dizer, crônicas; textos de reflexão, sermões de louvor ou censura, em uma palavra retórica; ou são poesia; ou por último são História, na qual o indivíduo acha-se retratado e julgado pelo que é e pelo que não é, por sua atividade, pelo que faz e pelo que ultrapassa. Estas últimas biografias não diferem de nenhuma outra História nem ainda do estilo dominante da forma literária. Mas, as biografias novelas não pretendem situar-se entre nenhuma destas quatro classes de obras; nem são como as boas novelas históricas antigas do passado, nas quais o juízo histórico expressava-se em narraçōes de sucessos imaginários para refletí-los e descrevê-los" (39).

Porém, a crítica da biografia novelada - a cujos autores nos referimos pela razão de serem sobejamente conhecidos e nem sempre terem os valores literários que desculpavam Scott - não nos devem fazer esquecer o judicioso de certas asseverações suas. E' inegável que, em benefício da Cultura, a Biografia deve continuar integrando a História; porém, o que é lícito fazer, procurando tirar proveito das vantagens da novelística.

Em primeiro lugar, não deve descuidar-se do valor artístico da forma como apresenta o trabalho histórico. Nenhum gênero da História permite que essa exigência seja cumprida tão cabalmente como na biografia.' E' sugestiva a insistência

(39). - Croce, ob. cit., págs. 24 e 25. 
com que todos os tratadistas europeus citam Carlyle a pro- pósito dêstes assuntos. Em páginas anteriores reproduzimos algumas de suas palavras muito eloqüentes e.o próprio George Macaulay Trevelyan disse:

"A verdade é o critério do estudo histórico, porém c seu móbil é de ordem poética. Sua poesia consiste em tornar-se verdade. E' aí que encontramos a sintese do aspecto científico e literário da História" (40).

Nas palavras de Croce referentes à autêntica biografia a histórica - pode-se ver que se leva em conta a complexidade do personagem histórico e por fim os motivos e estados anímicos do mesmo.

"O biógrafo deve, desde logo, ser em primeiro lugar historiador, mas, é necessário que seja também psicólogo e artista".

A biografia poderá desalojar a falsa biografia novelada usando as suas mesmas armas na defesa da Verdade que caracteriza a História.

A tendência de desvincular a História das formas artísticas afastando até a sombra da história novelada que se abandonaria à Literatura, apresenta-se sempre. Este movimento que corresponde à absoluta desvinculação entre a História e a Literatura - seria possível por meio dos esquemas sociológicos. E. Fueter, espera que com o prevalecimento dos critérios científicos sociológicos sôbre os juízos subjetivos, a História não terá necessàriamente que empreender a "luta com a Novela".

Trevelyan responde a esta situação, que estuda as conseqüências da aparição da biografia novelada, quando diz:

"A Literatura e a História são duas irmãs inseparáveis. A História não é. a rival da literatura clássica ou moderna ou das Ciências Políticas. E', bem mais, a casa onde estas habitam. E' o elemento com o qual se une todos os estudos relativos à natureza e às realizações do Homem" (41).

Uma ressonância da evoluçã̃o que apontamos é a exacerbasão do escrúpulo da verdade no historiador.

Torna-se a ouvir a voz do Dr. Johnson, dizendo:

"O valor de tôda História depende de sua verdade. Uma História é a pintura tanto de um individuo como da natureza humana. Se é falsa, não é pintura de nada".

(40). - Ob. cit., pag. : 14.

41). - History and the reader, London National Bood League, 1945, pág. 11. 
Esta afirmação, aplicada em princípio à biografia é extensiva a tôda a História.

\section{Situação atual do problema.}

Huizinga, no trabalho que temos utilizado, diz:

"A História é a ciência que mais depende das outras. Precisa mais que qualquor outra de auxílios e apoios contínuos, para formar suas noções, para fixar suas normas, para encher suas bases. Tôdas as ciências irmãs são por sua vez ciências auxiliares ao entendimento histórico... Porém não depende só de outras ciências como também da cultura, da vida mesma; porque suas perguntas e suas respostas são as mesmas que as da vida para o individuo e para a sociedade; porque os conhecimentos que se possui da vida pessoal ou coletiva, passam por uma transição imperceptível a ser História. Nesta relação indestrutível com a vida reside para a História a sua debilidade e a sua fôrça".

Seria impossível pretender um pórtico mais amplo para colocar a existência de interrelações profundas entre a História e a Novela a modo de experiência na evolução que estamos seguindo, que se faz presente até os nossos dias.

Para quem a formação cultural não se apresenta como uma tàrefa metódica, senão como uma aventura confusa, sente a atração por ambas coisas, pela curiosidade de conhecer outras vidas. Essa atitude não nos interessa neste momento, como tão pouco a oposta, e igualmente artificiosa dos especialistas em História e em Literatura que não compreendem a necessidade do desenvolvimento continuado do saber. Referimo-nos concretamente aos intelectuais e pensadores não eśpecializados e a seu amplo título hum:ıno de homem culto, de common reader. E' neste que se encontra expontânea essa mesma atitude mental com referência à História e à Novela. Sempre nos seduziu o possível paralelo entre Valery e Wells. E' notório que o escritor francês não àcredita na História e atreve-se a dizê-lo com a mesma energia, porém, sem os fundamentos com que o fazia a quatro séculos Descartes. $O$ inglês, preocupado com a análise de sua época e os problemas do mundo, entendia que não era possível haver nenhumà opinião raliosa sem o conhecimento da História e dêsse conhecimento especialmente forjado para isso brotou a sua Outline of History.

(42). - ob. citts pág. 374-375. 
O reverso dessa atitude dessemelhante está na conhecida atividade de $\mathrm{H}$. G. Wells no terreno da novelística onde produziu obras numerosas e onde em sua autobiografia celebrizou o gênero. $E^{\prime}$. menos conhecida e responde fielmente ao paralelo a atitude do escritor francês que se recusou expressamente a escrever novelas e execrou o gênero de forma tão terminante como o fêz com a História.

Talvez o motivo, que por sua presença ou defeito, explica as duas atitudes é a existência do interêsse político, em seu sentido etimológico, que tem como sêlo a História e em seu seio, em diversas ocasiões invisível, a Novela.

Depois disto é fácil chegar à conclusão de que ambas ocupações facilitam um melhor conhecimento do homem e da vida social, em maior grau do que o que poderia ministrar a Filosofia. Ernst Cassirer é explícito ao dizer:

"A Arte e a História representam os instrumentos mais poderosos ern nosso estudo da natureza humana. Que conheceríamos do homem sem estas duas fontes de informações? Dependeríamos dos dados de nossa vida pessoal... e teríamos que fazer experiências psicológicas, recolher fatos estatísticos, mas, nosso retrato do homem seria inerte e sem côr. Nas grandes obras de História e de Arte começamos a ver, por trás desta máscara de homem convencional, os rasgos do homem real, individual. Para encontrá-lo temos que recorrer aos grandes historiadores e aos grandes poetas, aos escritores trágicos como Eurípedes e Shakespeare, ou aos escritores cômicos como Cervantes, Molière e Lorenzo Sterne, ou ainda a novelistas modernos como Dickens, Thackeray, Balzac, Flaubert, Gogol ou Dostoievsky. A poesia não é mera imitação da natureza; a História não é uma narração de fatos e de acontecimentos mortos. A História, como também a poesia, é um órgão do conhecimento de nós mesmos, um instrumento indispensável para construir nosso universo humano".

Esse conhecimento da natureza humana, em diversas ocasiões tem sido interpretado como exemplo. Já Macaulay dizia:

"Mas, nenhum homem que conheça devidamente o passado se sentirá disposto a aceitar uma visão deformada ou desalentadora do presente"

e, Croce, intitulava seu livro, tantas vêzes aqui citado, na edição original La Storia come pensiero e come azione. E' vá-

(43). - Macaulay, História da Inglaterra, ob. cit., voł. I, cap. I. 
lido pedir o mesmo à Novela num plano menor e mais relativo e como vimos esta assume a atitude correspondente.

À Novela caberia inclusive complementar os dadós gerais proporcionados pela História, pois, como disse o escritor inglês Forster:

"O historiador trata das ações e do caráter dos hömens, na única medida em que pode deduzí-los de suas ações. Ocupa-se de caracteres tanto quanto o novelista. porém só conhece a existência do caráter quanto êste aflora à superfície" (44).

Isto requer uma explicação mais ampla para que fique mais claro. Essas vantagens da Novela - como dizia Cassirer mais acima - são prór,rias a tôda a Literatura. Por Novela entendemos a contemporânea da época do sucesso histórico, e nunca a novela histórica ou a biografia novelada.

Isto leva-nos à terceira consideração dentro das relações História-Novela. E' a referente à qualidade artística que deve ser exigida à História em suas formas. Deliberadamente temos deixado de lado, por considerá-lo falto de interêsse e apenas apto a criar confusão, o debate que considera se a História é uma Arte ou uma Ciência. Acreditamos, e já o dissemos, que é Ciência no que respeita aos seus métodos, fins, conceitos e conteúdo, porém, pode ser Arte quanto à sua forma. E' útil ressaltar êste ponto quando se trata da Biografia (45).

No fundo, a questão demonstra a verdade das palavras de Menéndez y Pelayo, quase perdidas entre os conceitos superados sôbre êste ponto, quando disse no seu discurso na Academia:

“Assim, bem podemos afirmar que não há dois mundos distintos, um da poesia e outro da História, porque o espírito humano, que cria uma e outra, e ao mesmo tempo as executa e escreve é o mesmo" (46).

Do comentário da frase de Forster surge, também, a quarta relação destacável, que consiste em que a Novela em geral, f em especial a contemperânea, constitui um material documental de primeira ordem. São amplamente conhecidas as reconstruções baseadas em textos poéticos. Nas histórias sôbre a Gré-

(44). - Do Aspects of the novel, 6a. edição, págs. 156, Arnold, Londres, 1944.

(45). - Veja-se o capítulo History as a branch of literature na obra de Herbert Butterfield, History and human relations. Londres, Collins, 1951, 3a. edição, págs. 225-254.

(46). - De la Historia considerada como obra artística, veja-se págs. 81 e 135 do tomo I dos Estudios de crítica literaria. Madri, 1893. 
cia, baseando-se nos poemas homéricos e na história da Espanha com base no Poema Mío Cid (v. g. a interessante A Espanha do Cid de Menéndez y Pidal). Com maior razão, a Novela pode servir aos fins da investigação histórica. Anotava Don Marcelino Menéndez y Pelayo a propósito do Livro do Bom Amor:

"Vale tanto como fonte histórica, que se nos faltasse, ignoraríamos todo um aspecto da Idade Média do mesmo modo que seria possivel conhecer a Roma Imperial sem a novela de Petrônio, mesmo que Tácito se tivesse conservado inteiro" (47).

Resulta valiosíssima, com maior razão, a novela contemporânea, de acôrdo com o desenvolvimento dado anteriormente. I.ewis Munford disse:

"as poesias, obras e novelas contemporâneas possuem uma classe de veracidade que não se encontra nos arquivos dos tribunais, nos livros de contabilidade, nem nos recortes dos jornais" e acrescenta "contém o homem vivo e o que o rodeia no grau máximo que permite sua reação ao meio ambiente e sua capacidade de expressão" (48).

Em reverso do anterior, e em definitivo, a quinta questão, em que se coloca estas vinculações úteis que estamos seguindo, é a necessidade que existe, para a compreensão da novela e da literatura em geral, do estudo histórico.

Sigamos Croce:

"Sem a trađição da crítica histórica, o gôzo de tôdas, ou de quase tôdas as obras de arte haver-se-ia perdido irremissivelmente; seríamos pouco mais do que animais, submersos apenas no presente num passado imediato" (49),

o que neste ângulo também o confirma Menéndez y Pelayo quando diz, falando concretamente do ensino da literatura:

"O desenvolvimento dos estudos históricos fêz notar as relaçōes infinitas entre a arte e as demais aitvidades humanas que naturalmente se completam e explicam. Dai a necessidade do critério histórico além do estético. De acôrdo com o período que se estuda deve predominar um ou outro. As produções da Idade Média, v. g., têm

(47). - Antología de Poetas líricos castellanos. Mađrí, 1923, tomo III.

(48). - La cultura de las ciudades, ed. cit., tomo III, pág. 29.

49). - Estética, Madrí, 1926 (segunda edição espanhola), caps. IV e XVIr. A citação é da pág. 166. 
um intérêsse maiś arqueológico e histórico que pròpriamente estético" (50).

Ainda que isto tenha sido dito pelo ilustre poligrafo no ano de 1878 , que propugnava em seu programa que o ensino da literatura deve estar presidida pelo critério duplo do juízo estético e a apreciação histórica, é sobremaneira notório que se insiste, entretanto, em aulas de simples exegese, numa busca repetida de beleza, sem relação alguma com o mundo em que se formou a obra 'mstra. E' no terreno pedagógico que também se apresenta a sexta vinculação que se refere à utilização de novelas históricas para o ensino da História. Já vimos como Huizinga e Croce, a propósito da biografia - apressavam-se a absolver a Novela Histórica das críticas justíssimas que correspondem à biografia novelada, com a qual não deve confundir-se e nem ser tomada como simples prolongação como eqüivocamente $o$ fêz Amado Alonso.

Seu papel no ensino não poderá ser medido, pelas pretensões da novela romântica de que demos conta, mas sim pelo critérió rigoroso do professor que deverá discriminar as obras úteis para êste fim, e áinda, acentuar nelas as falhas e erros científicos que por acaso existam, prèviamente à sua leitura.

Na prática observa-se que esta classe de obras é da preferência dos jovens e dos autodidatas, pelo que não se justificam nem as críticas de Manzoni (que repete Amado Alonso) nem a prevenção pedante de Ortega quando expressa:

"O novelista intenta anestesiarmos para a realidade, deixando o lcitor recluso na hipnose de uma existência virtual... Encôntro aqui - a causa nunca bem declarada, da enorme dificuldade - talvez da impossibilidade: anexa à chamada novela histórica. A pretensão de que o cosmos imaginado possua por sua vez autenticidade histórica, mantém naquela uma colisão permanente entre os horizontes. E, como cada horizonte exige una acomodação distinta de nosso aparelho visual, temos que constantemente mudar de atitude; não se deixa o leitor sonhar tranqüilo na Novela, nem pensar rigorosamente na História. Em cada página vacila, não sabendo se projetar o fato e a figura: sôbre o horizonte imaginário ou sôbre o histórico, com o qual adquire todo um ar de falsidade e de convenção. O intento de apresentar ambos os mundos só logra a mútua negação de um e outro - parece-nos.

(50). - Introducción y programa de literatura española. Utilizamos a veraáo que se acrescenta à mencionada edição das orígenes de la novela, ob. cit., tómo IV, págs. 228-229. 
- falsifica a história com uma aproximação demasiada edisvirtua a novela afastando-a dos leitores até o plano abstrato da verdade histórica" (51).

Esta situação poderia ser certa neste autor ou em qualquer que unisse em sua pessoa a capacidade estética e o conhecimento exaustivo de uma época; porém, evidentemente não está no. caso dos leitores comuns.

Referindo-nos às experiências feitas no Uruguai, no Ensino. Secundário, recordamos o trabalho apresentado por Daniel Cas-. tellanos por ocasião de seu concurso para a Cátedra de História. Universal, onde recomenda a inclusão de lẹituras

"com o propósito de facilitar aos alunos uma vista de. olhos sôbre a psicologia de determinada época". Insistia: conjunto sôbre determinado acontecimento histórico ou "Tendo para mim, que certas grandes sinteses só o Artista realiza", a "História deve ser estudada como uma matéria essencialmente viva" e à pergunta "que métodos: deve-se pôr em prática para que o estudante dê vida à História? "replica: "Nada é mais indicado a êste respeito. do que recorrer à ajuda de uma faculdade notável de nosso espírito: a imaginação: (52). Acrescenta, desenvolven-. do êste pensamento: "A imaginação se educa, se afina; em suma torna-se mais sensível utilizando certas obser-vaçôes salientadas pelo professor, leituras da indole que. indica o programa, novelas hiștóricas, e comparações trazidas com certa arte".

A novela histórica será sempre preciosa para saber-se o ín-. dice de interêsse histórico de uma época e como esta encara o passado de acôrdo com suas necessidades intelectuais concretas (53).

Finalmente há um mérito a favor da novela histórica que. por si só faz a sua defesa. Referimo-nos à sua importância no. despertar da vocação para a História.

As relações anotadas de utilidade prática - como dizíamos a princípio - sằo definitivamente uma versão superficial do imenso desenvolvimento alcançado pela História e da cons-.ciência cada vez mais difundida de que os feitos da cultura são

"resultantes de um desenvolvimento que pode seguir-. se no passado explicando-o",

quer dizer, do historicismo.

(51). - Ob. cit., pág. 943 .

(52). - La Ensefianza de la Historia Universal. Montevidéu, 1915, págs. 90, 103 e 104.

(53). - Não demais dizer que repelimos as mistificaçöes do tipo de Dumas, Zevaco, M. Mitchell, K. Windsor, etc. 
As tentativas de ordenar os conhecimentos distintos tendem de uma maneira insistente a colocar a História como pensamento diretor de um vasto setor da realidade.

A concepção que explica o pensamento de acôrdo com os fatos históricos, obriga o reconhecimento da historicidade do espírito e não só que a história da Filosofia mas, que a Filosofia mesma, passam a integrar o amplo núcleo da História.

Croce ao encerrar seu livro diz:

"A Poesia e a Historiografia são, pois, duas alas do mesmo organismo que respira, dois momentos ligados entre si, do espírito que conhece. Uma terceira ala que era mais potente que ambas nesta sua relação não existe; a filosofia é um momento do mesmo pensamento histórico como o conceito o é do juízo, e fora do eu não há vida, pois, não pode-se considerar vivos êsse monte de coisas abstratas que tomam o nome de filosofia nos tratados e nas dissertações escolares" (54).

Um ponto de vista bem diverso dêste é o que sustenta Toynbee, que citamos com os reparos já anotados. Sustenta que

"há três métodos diferentes para contemplar e apresentar os objetos de nossó pensamento, e entre êles, os fenômenos da vida humana... que correspondem a uma distinção igualmente clara entre os respectivos fenômenos que são contemplados e apresentados por essas formas diferentes. Assim, a comprovação e registro dos fatos particulares é a técnica da História, e os fenômenos que se encontram no campo dessa técrica são os fenômenos sociais das civilizações. A elucidação e formulação de leis gerais é a técnica da ciência; e no estudo da vida humana, a ciência é a antropologia e os fenômenos que se encontram no campo da técnica cientifica são os fenômenos sociais das sociedades primitivas. A ficção é a técnica do teatro e da novela; e os fenômenós que se acham no campo desta técnica são as relações pessoais entre os sêres humanos" (55).

Entretanto, não havia incompatibilidade absoluta entre è̀stes três setôres, pois, em outra parte acrescenta que a medida que os dadós e feitos (para êle sinônimos) vão aumentando, a História poderá com a técnica da Ciência, inclusive 
mediante à Ficção - igual à Novela - chegar a possuir numerosos fatos e dados (56). Finalmente

"há certas obras literárias que por sua forma são obras de ficção",

porém ficam sob a categoria de "História" porque têm como tema não as relações pessoais entre sêres humanos, mas os assuntos públicos (57) e cita entre estas Os persas de Ésquilo, The Dynast de Hardy e O Judeu Sus de Feuchtwanger.

Qual é o lugar da Arte na História, e por fim da Novela nesta reordenação da cultura que nossos dias presenciam?

Torna-se difícil predizer em razão da complexidade do tema, o porvir das relações entre a História e a Literatura.

Estão, naturalmente, condicionados ao desenvolvimerto que ambos assuntos venham a sofrer e à reação que a sociedade adote ante suas realizações. Não faltam vozes agoureiras que refiram-se a um esgotamento futuro de ambas as formas. Compara-se a Novela de nossos dias à do século XVI e teme-se pela desintegração da História em ciências independentes que quebram seu valor centrípeto.

O tema continuará colocando-se cada vez em forma mais imperativa pois, como dizia Ortega y Gasset

"Pode-se vaticinar, sem risco excessivo, que fora a filosofia, as emoções mais poderosas que o futuro próximo nos reserva virão da História e da Novela".

CARLOS M. RAMA

Professor da Universidade de Montevidéu.

(56). - Ob. cit., págs. $497-498$.

(57). - Ob. cit., pág. 489. 